\title{
Compact string reactor for autothermal hydrogen production
}

\author{
C. Horny, A. Renken, L. Kiwi-Minsker* \\ École Polytechnique Fédérale de Lausanne, EPFL-LGRC, CH-1015 Lausanne, Switzerland
}

Available online 22 August 2006

\begin{abstract}
This study addresses the development of a compact reactor for oxidative steam-reforming of methanol (OSRM) to produce hydrogen in autothermal mode for fuel cells. The string reactor uses catalytically active brass wires with a diameter of $500 \mu \mathrm{m}$ placed in parallel into a tube. The micro-channels in the reactor for gases are formed between the wires presenting hydrodynamics similar to the one in multi-channel micro-reactors. Due to the high thermal conductivity of brass, the heat generated during methanol oxidation at the reactor entrance is transferred to the zone of the endothermic steam-reforming. The catalysts are prepared by Al-alloy formation on the surface of the brass wires followed by the partial leaching of $\mathrm{Al}$. The catalyst presents a porous layer with the morphology of Raney metals and the chemical composition consistent with the Cu/Zn/Al-mixed oxide. The catalyst surface was additionally modified by incorporating chromium leading to $\mathrm{Cr} / \mathrm{Cu}$-spinel. This decreases the degree of the reduction of copper oxide and sintering leading to a stable catalyst. The catalyst was tested in OSRM showing high activity and selectivity to carbon dioxide and hydrogen. The string reactor presents nearly isothermal profile since the temperatures gradient within the reactor length is about $3 \mathrm{~K}$. Micro-structured string reactor presents a short start-up and a fast transient behavior showing a rapid temperature change when adjusting the oxygen amount introduced into the reactor.
\end{abstract}

(C) 2006 Elsevier B.V. All rights reserved.

Keywords: Autothermal hydrogen production; Methanol; Oxidative steam-reforming; Brass-wire catalysts; Micro-structured reactor; Hot-spot; Raney metal

\section{Introduction}

Methanol is considered for "automotive" fuel cells as hydrogen source due its safe handling, low cost and high storage density. Moreover, it can be produced from biological, i.e. renewable sources [1]. Between different reactions, steamreforming (SR) gives the highest hydrogen concentration (up to $75 \%)$ :

$$
\mathrm{CH}_{3} \mathrm{OH}+\mathrm{H}_{2} \mathrm{O} \rightarrow \mathrm{CO}_{2}+3 \mathrm{H}_{2}, \quad \Delta_{\mathrm{r}} H^{0}=49 \mathrm{~kJ} \mathrm{~mol}^{-1}
$$

The amount of $\mathrm{CO}$ generated along $\mathrm{CO}_{2}$ according the reaction (1), is low. This is important since it acts as a poison for fuel cells. The accepted levels of $\mathrm{CO}$ are between 10 and $100 \mathrm{ppm}[2,3]$.

The main disadvantage of SR is its endothermicity requiring external heating, which makes short start-up and fast transient behavior difficult to achieve [4].

\footnotetext{
* Corresponding author. Fax: +41 216933190.

E-mail address: lioubov.kiwi-minsker@epfl.ch (L. Kiwi-Minsker).
}

The exothermic partial oxidation of methanol (POX) can be used for fast dynamic in reforming systems:

$$
\mathrm{CH}_{3} \mathrm{OH}+0.5 \mathrm{O}_{2} \rightarrow \mathrm{CO}_{2}+2 \mathrm{H}_{2}, \quad \Delta_{\mathrm{r}} H^{0}=-193 \mathrm{~kJ} \mathrm{~mol}^{-1}
$$

But the formation of hot-spots in the catalytic bed is the main drawback: it leads to catalyst sintering resulting in the activity loss [5]. Combined SR and POX is known as oxidative steamreforming of methanol (OSRM) which gives fast dynamics and generates high hydrogen concentrations:

$$
\begin{aligned}
& \mathrm{CH}_{3} \mathrm{OH}+(1-2 a) \mathrm{H}_{2} \mathrm{O}+a \mathrm{O}_{2} \rightarrow \mathrm{CO}_{2}+(3-2 a) \mathrm{H}_{2}, \\
& \Delta_{\mathrm{r}} \mathrm{H}(298 \mathrm{~K})=49.5-484.8 \mathrm{a} \mathrm{kJ} \mathrm{mol}^{-1}
\end{aligned}
$$

Reactors for this process operate autothermally, i.e. it does not require any external heating or cooling once the operational temperature is reached. For fast transient response, the methanol/oxygen ratio can be varied as in the case of the Hot-Spot ${ }^{\circledR}$ reformer [6].

OSRM takes place over copper/zinc/alumina (CZA) catalysts with high activity and selectivity to $\mathrm{CO}_{2}$ and $\mathrm{H}_{2}$. Optimum feed composition was reported having oxygen to methanol and water to methanol ratios of $0.2-0.3$ and 1.3-1.6, 
respectively [7-9]. The excess steam serves to reduce $\mathrm{CO}$ content by water-gas shift reaction:

$\mathrm{CO}+\mathrm{H}_{2} \mathrm{O} \leftrightharpoons \mathrm{CO}_{2}+\mathrm{H}_{2}, \quad \Delta_{\mathrm{r}} H^{0}=-39.5 \mathrm{~kJ} \mathrm{~mol}^{-1}$

\section{Reactor concept}

The main difficulty in carrying out OSRM is due to the fast methanol oxidation compared to the steam-reforming. As a consequence, heat is generated mostly at the reactor entrance, whereas the heat consumption occurs in the middle and rear of the reactor. In conventional reactors with randomly packed catalytic beds, low axial and radial heat conductivity leads to substantial axial temperature profiles. A hot-spot at the reactor entrance and a "cold-spot" in the second part of the reactor were observed [10]. A high temperature damages the catalyst. On the other hand, a low temperature decreases the rate of the reforming reaction. Therefore, temperature control in the reactor is crucial for an efficient and stable reactor performance.

Metal-based catalysts with high thermal conductivity allow combining exothermic combustion of methanol and endothermic steam-reforming. The beneficial effect of improved heat transfer was demonstrated for the OSRM using either a conductive material [11], or channel micro-geometry of a monolith [12].

In the present study, a compact String reactor ${ }^{\circledR}$ is applied for OSMR [13-15]. The reactor consists of a tube with a diameter in the centimeter range where thin metallic catalyst wires are introduced with diameters of $500 \mu \mathrm{m}$ (Fig. 1). The reacting gases flow between the wires. The string reactor presents a flow hydrodynamics similar to multi-channel micro-reactors $[13,15]$ and ensures laminar flow, narrow residence time distribution and low pressure drop through the catalytic bed. Brass wires with high heat conductivity $(118 \mathrm{~W} /(\mathrm{m} \mathrm{K}))$ were chosen as catalyst due to their chemical composition (alloy of $\mathrm{Cu}$ and $\mathrm{Zn}$ ) close to the conventional CuZnAl-mixed oxide catalyzing the OSRM.

\section{Experimental}

\subsection{Catalyst preparation}

The brass-wires CuZn37 (from Goodfellow) containing $37 \mathrm{wt} . \%$ of zinc were used as catalyst. The specific surface area
(SSA) of the wires corresponds to their geometric surface per volume and therefore, they did not show any catalytic activity [15]. To obtain metal wires with high SSA, a thin $\mathrm{Cu} / \mathrm{Zn} / \mathrm{Al}$ alloy is formed on the wire surface. Then, aluminium is leached out resulting in a thin porous layer with a morphology similar to that of Raney metals [16]. Aluminium leaching is carried out either in an acid or a basic solution. The acid leaching uses boiling $\mathrm{HCl}$ aqueous solution (3.7 wt.\%) during $20 \mathrm{~min}$. The catalyst treated by this acid leaching is named CZA.

The leaching by basic medium is carried out simultaneously with a metal doping by two different methods: impregnation (of chromium) or precipitation (of chromium, zirconium or cerium). Leaching of aluminium and impregnation with chromium were performed using $\left(\mathrm{NH}_{4}\right)_{2} \mathrm{Cr}_{2} \mathrm{O}_{7}(0.004 \mathrm{M})$ in an aqueous solution of $\mathrm{NaOH} 6.1 \mathrm{M}$ at $273 \mathrm{~K}$ during $72 \mathrm{~h}$. The resulting catalyst is $\mathrm{CZACr} / \mathrm{i}$. Metal precipitation together with aluminium leaching is carried out by using nitrate metals $\left(\mathrm{M}^{x+}\left(\mathrm{NO}_{3}\right)_{x}\right) 0.5 \mathrm{M}$ in an aqueous solution of $\mathrm{Na}_{2} \mathrm{CO}_{3} 0.1 \mathrm{M}$ at $333 \mathrm{~K}$ during $30 \mathrm{~min}$. When adding $\mathrm{Cr}$, $\mathrm{Zr}$ or $\mathrm{Ce}$, the catalysts were named after the dopant as CZACr/p, CZAZr/p and $\mathrm{CZACe} / \mathrm{p}$. After rinsing in water, catalysts were calcined in air at $723 \mathrm{~K}$ for $2 \mathrm{~h}$, and before testing reduced by $10 \% \mathrm{H}_{2}$ in $\mathrm{Ar}$ at $523 \mathrm{~K}$ during $2 \mathrm{~h}$ in the reactor.

\subsection{Characterization of the catalysts}

The specific surface area of the samples was measured by nitrogen adsorption using a Sorptomatic 1990 (Carlo Erba) instrument and calculated applying BET method.

SEM images were obtained with a SEM JSM 6300 (JEOL USA, Inc., Peabody, MA, USA) apparatus.

Temperature-programmed reduction (TPR) and oxidation (TPO) were carried out in a Micromeritics AutoChem 2910 apparatus by passing, respectively, the flows $(20 \mathrm{ml} / \mathrm{min}$ (STP)) of 4 vol. $\% \mathrm{H}_{2}$ in $\mathrm{He}$ and 2 vol. $\% \mathrm{O}_{2}$ in He through the sample (ca. $150 \mathrm{mg}$ ). The temperature was increased from room temperature to $1073 \mathrm{~K}$ at a rate of $10 \mathrm{~K} / \mathrm{min}$. The outlet concentrations were monitored by a mass spectrometer (Thermostar 200, Pfeiffer Vacuum) to obtain TPO and TPR profiles.

$X$-ray photoelectron spectra $(X P S)$ was performed with a Kratos AXIS Ultra, UK. The binding energies of $\mathrm{Cu} 2 \mathrm{p}$ were referenced to the $\mathrm{C} 1 \mathrm{~s}$ peak at $285.2 \mathrm{eV}$, giving binding energies with $\pm 0.2 \mathrm{eV}$ experimental error.
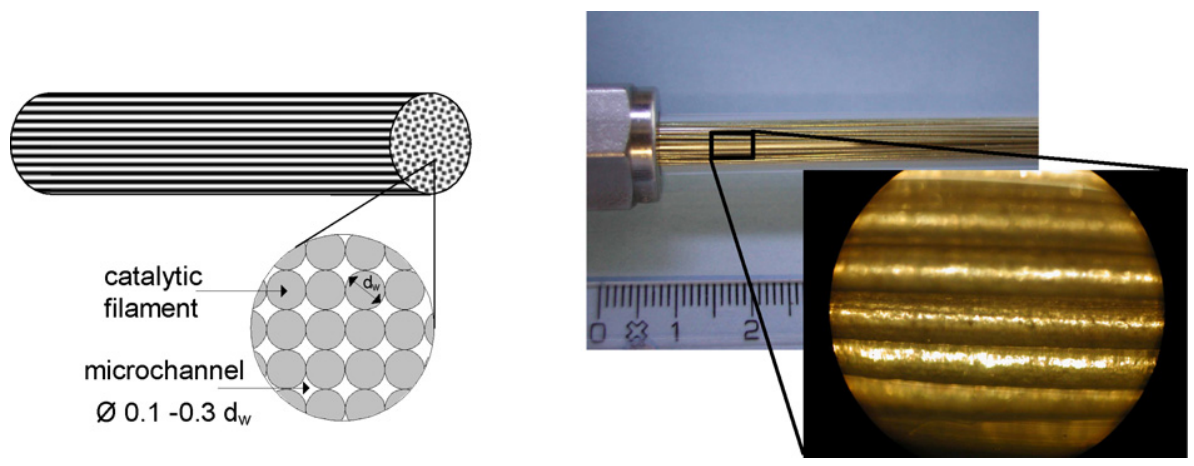

Fig. 1. Schematic presentation and photograph of the compact string-reactor. 


\subsection{Experimental set-up and reaction conditions}

The reactions were performed at $1.32 \times 10^{5}$ Pa pressure and temperatures between 473 and $573 \mathrm{~K}$. The ratios of water to methanol and oxygen to methanol were 1.0 and 0.12 , respectively, with argon as diluting gas.

A tubular glass reactor (inner diameter: $9 \mathrm{~mm}$, length: $110 \mathrm{~mm}$ ) was filled with 217 catalytic active metal rods (39.4 g) and placed in a furnace. In the middle of the catalytic bed, a thermocouple with a stainless steel sheath was inserted. The thermocouple with the same dimension as the metal rod could be displaced axially to measure the axial temperature profile. Pre-mixed water-methanol was fed to a vaporizer (Bronkhorst High-Tech B.V.) heated at $398 \mathrm{~K}$ with argon as carrier gas. Gas and liquid flows were adjusted by Bronkhorst mass flow controllers. The whole installation was maintained at $423 \mathrm{~K}$ in order to avoid condensation in the tubing. The feed and product gases were analyzed by on-line gas chromatography (Hewlett Packard, HP 6890, capillary column: Supelco Carboxen 1010) with a thermal conductivity detector.

\section{Results and discussion}

\subsection{Influence of chemical composition and preparation method on catalyst performance}

Oxidative steam-reforming of methanol was carried out over brass-based catalysts, leached in an acidic solution (CZA) or doped and leached in a basic solution. The modification of the catalyst was performed by impregnation or by precipitation $(\mathrm{Cr}$, $\mathrm{Zr}, \mathrm{Ce})$. Fig. 2 shows methanol conversion and hydrogen production for different catalysts under the same conditions. Those prepared by the precipitation, demonstrated very low activity with methanol conversion of $10-18 \%$ and hydrogen production of less than $0.2 \mathrm{~mL} /\left(\mathrm{g}_{\text {cat }} \mathrm{min}\right)$. At the same time formaldehyde and formic acid were detected. These secondary products are formed by dehydrogenation or partial oxidation of methanol in line with the results reported in literature [17-19].
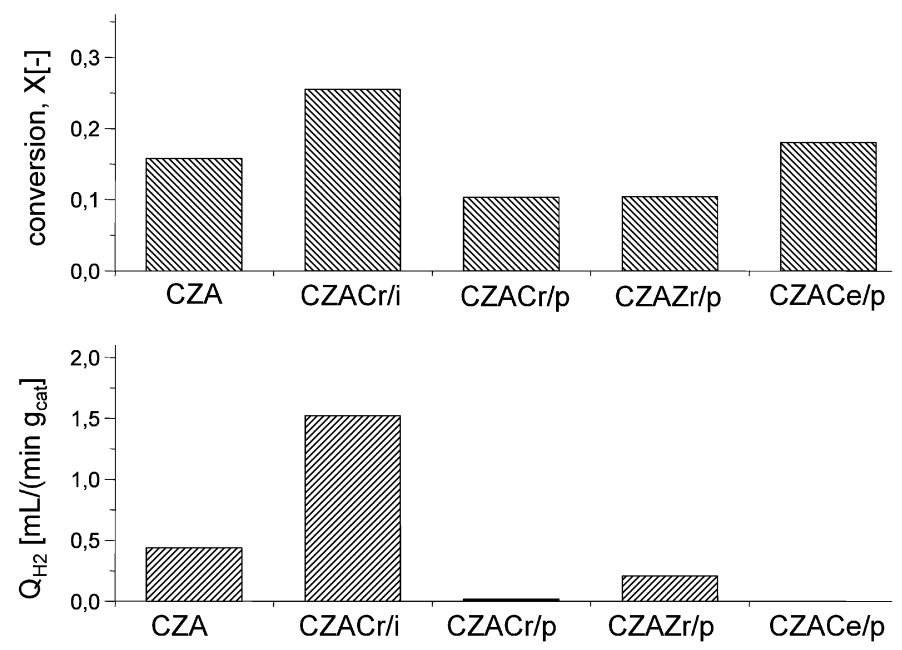

Fig. 2. Oxidative steam-reforming of methanol: influence of additives and preparation methods on hydrogen production after $1 \mathrm{~h}$ of reaction. $T=537 \mathrm{~K}$; $\mathrm{W} / \mathrm{F}=0.3 \mathrm{~kg}_{\text {cat }} \mathrm{s} / \mathrm{mmol}$; total flow $=100 \mathrm{~mL} / \mathrm{min}$.

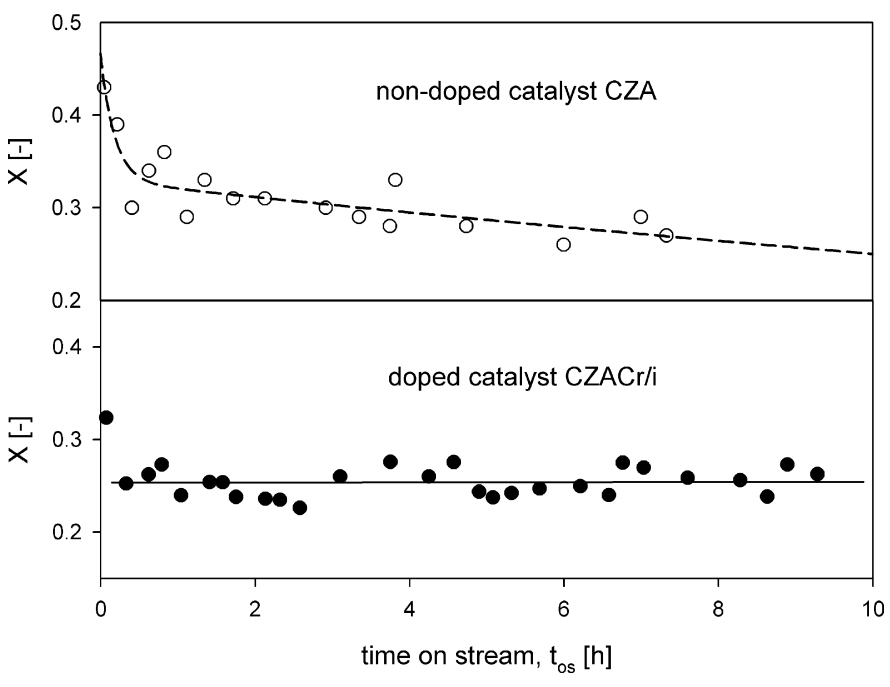

Fig. 3. Oxidative steam-reforming of methanol. Stability of the non-doped catalyst (CZA) and the Cr-doped catalyst $(\mathrm{CZACr} / \mathrm{i}) . \quad T=535 \mathrm{~K}$; W/ $\mathrm{F}=0.3 \mathrm{~kg}_{\mathrm{cat}} \mathrm{s} / \mathrm{mmol}$; total flow $=100 \mathrm{~mL} / \mathrm{min}$.

Impregnation of the Raney catalysts with chromium is known to improve the activity/selectivity of $\mathrm{Cu}$-based catalyst [20-22]. The experimental results obtained in this study and showed in Fig. 2 demonstrate the higher production of hydrogen of the catalyst doped with chromium by impregnation $(\mathrm{CZACr} / \mathrm{i})$. The higher stability of this catalyst is demonstrated in Fig. 3, where the methanol conversion is plotted as a function of time. Therefore, the $\mathrm{CZACr} / \mathrm{i}$ catalyst was used for further studies.

Non-treated brass rods gave no measurable methanol conversion under the chosen reaction conditions.

\subsection{Catalyst characterization}

\subsubsection{BET surface area}

Surface areas and methanol conversions of the non-doped and doped catalysts were measured before and after reaction and are reported in Table 1. In view of these results, the loss of activity during oxidative steam-reforming of methanol can be related to the loss of specific surface area. Indeed, because of the low Hüttig temperature, copper is highly sensitive to thermal sintering [23]. This process reduces the SSA decreasing the catalytic activity [23-25].

\subsubsection{SEM images}

The surface porosity is clearly seen by SEM images. Fig. 4 shows the surface morphology of the wires of CZA and

Table 1

BET surface area and methanol conversion before and after reaction of the nondoped (CZA) and the Cr-doped (CZACr/i) catalysts

\begin{tabular}{llllllll}
\hline Catalyst & \multicolumn{2}{l}{ Surface area $\left(\mathrm{m}^{2} / \mathrm{g}\right)$} & & \multicolumn{3}{l}{ Methanol conversion } \\
\cline { 2 - 3 } \cline { 7 - 8 } & Initial & Final & $\begin{array}{l}\text { Ratio } \\
\text { final/initial }\end{array}$ & & Initial & Final & $\begin{array}{l}\text { Ratio } \\
\text { final/initial }\end{array}$ \\
\hline CZA & 23.0 & 14.9 & 0.648 & & 0.430 & 0.270 & 0.628 \\
CZACr/i & 19.0 & 15.3 & 0.805 & & 0.324 & 0.253 & 0.781 \\
\hline
\end{tabular}


(a)

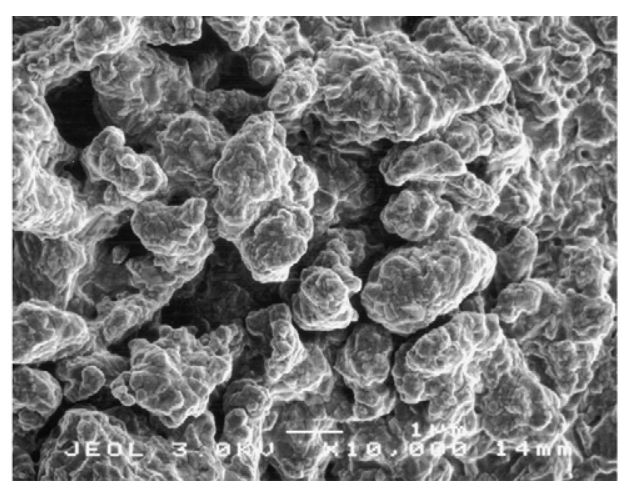

(c)

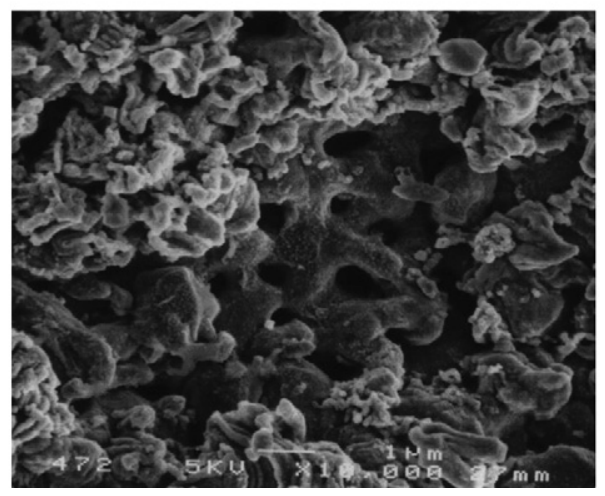

(b)

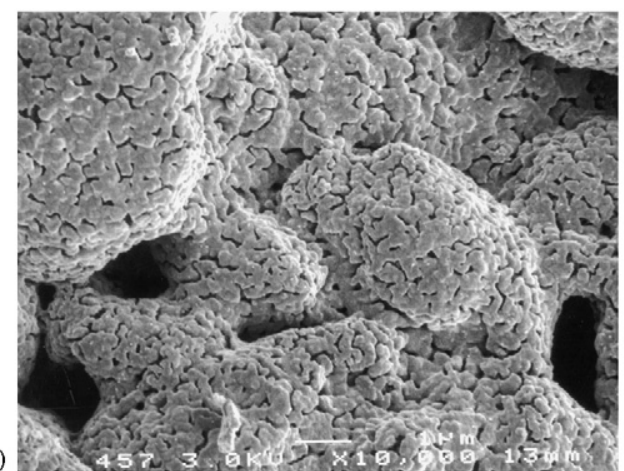

(d)

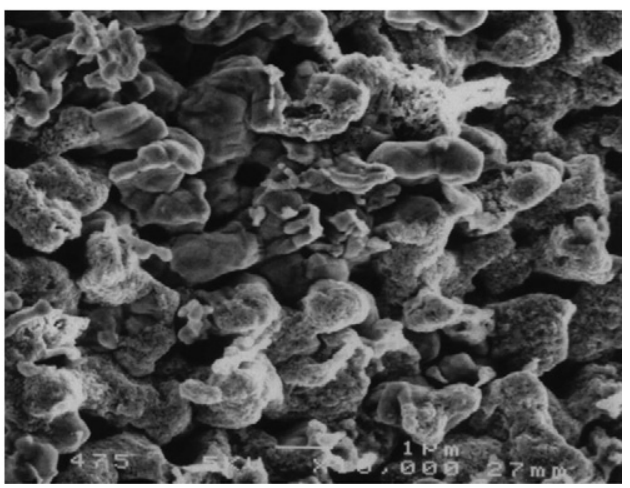

Fig. 4. SEM image of the surface: CZA after calcination (a) and after reduction (b); CZACr/i after calcination (c) and after reduction (d).

$\mathrm{CZACr} / \mathrm{i}$ after calcination and after reduction. The surface of the non-doped catalyst has been modified during reduction, whereas the one of the $\mathrm{Cr}$-doped catalyst remain unchanged.

\subsection{3. $X P S$}

Photoelectron spectroscopy was used to study the chemical state of the elements and their relative abundance at the catalyst surfaces. The binding energies of $\mathrm{Cu} 2 \mathrm{p}$ for $\mathrm{CZA}$ and $\mathrm{CZACr} / \mathrm{i}$ catalysts after oxidation and after reduction are summarized in Table 2 and the spectra are displayed in Figs. 5 and 6. For the non-doped catalyst, the $\mathrm{Cu} 2 \mathrm{p}$ profile changes dramatically upon $\mathrm{H}_{2}$-reduction. The calcined sample (Fig. 5(a)) displays a unique $\mathrm{Cu}$ peak at approximately $934 \mathrm{eV}$, which is characteristic of $\mathrm{Cu}^{2+}$ in $\mathrm{CuO}[26]$. In addition, the satellite peak at $\sim 943 \mathrm{eV}$ indicates $\mathrm{Cu}^{2+}$ ions, since it is considered as a charge transfer of ligand electrons to unfilled $3 \mathrm{~d}$ orbital $[27,28]$. The

\section{Table 2}

Binding energies values of $\mathrm{Cu} 2 \mathrm{p}(\mathrm{eV})$ for $\mathrm{CZA}$ and $\mathrm{CZACr} / \mathrm{i}$ catalysts after oxidation and after reduction

\begin{tabular}{lc}
\hline After calcination & After reduction \\
\hline CZA & \\
$933.7(100)$ & $932.5(70.0)$ \\
& $934.1(17.0)$ \\
& $935.4(13.0)$ \\
CZACr/i & \\
$934.0(5.8)$ & $932.8(11.0)$ \\
$935.0(94.2)$ & $934.1(39.0)$ \\
& $935.3(50.0)$ \\
\hline
\end{tabular}

Values in parenthesis are peak percentages. decrease of the satellite peak and the simultaneous shift of the principal $\mathrm{Cu} 2 \mathrm{p}$ peak towards lower binding energy upon $\mathrm{H}_{2}$-reduction (Fig. 5(b)) suggest that the copper species are transformed to $\mathrm{Cu}^{+}$or $\mathrm{Cu}^{0}(70 \%)$ [29]. The $\mathrm{Cu} 2 \mathrm{p}$ peak presents
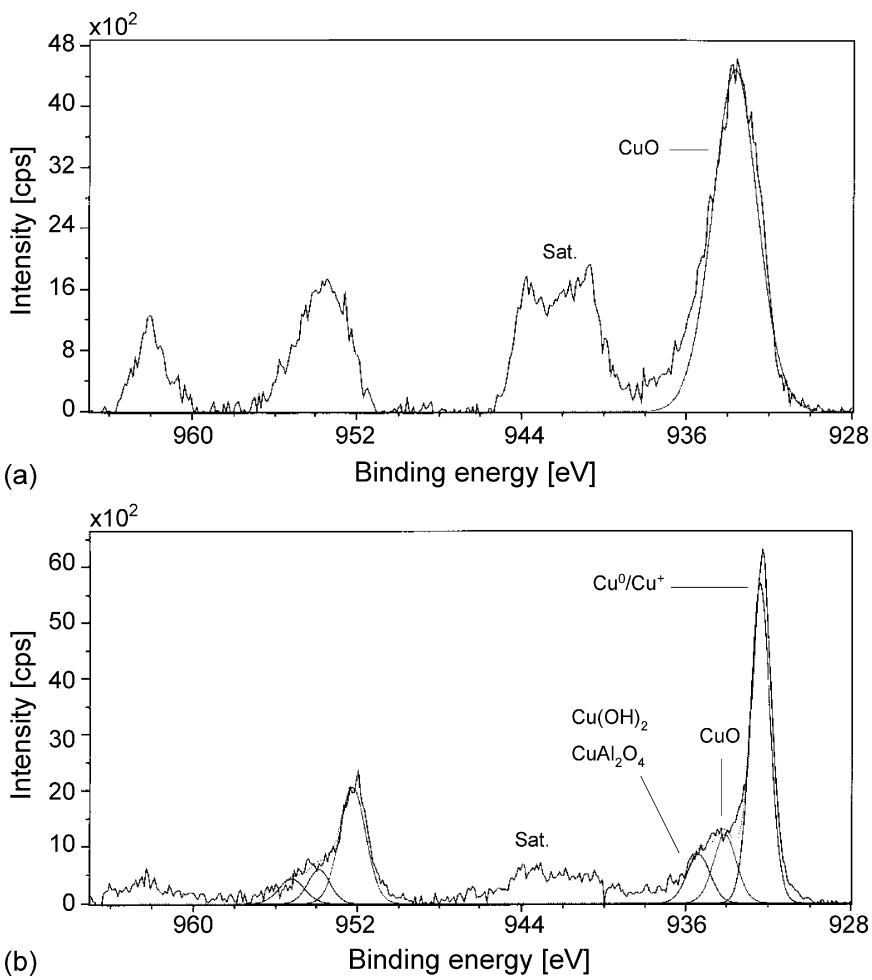

Fig. 5. Cu 2p X-ray photoelectron spectra of the non-doped catalyst (CZA) after calcination (a) and after reduction (b). 

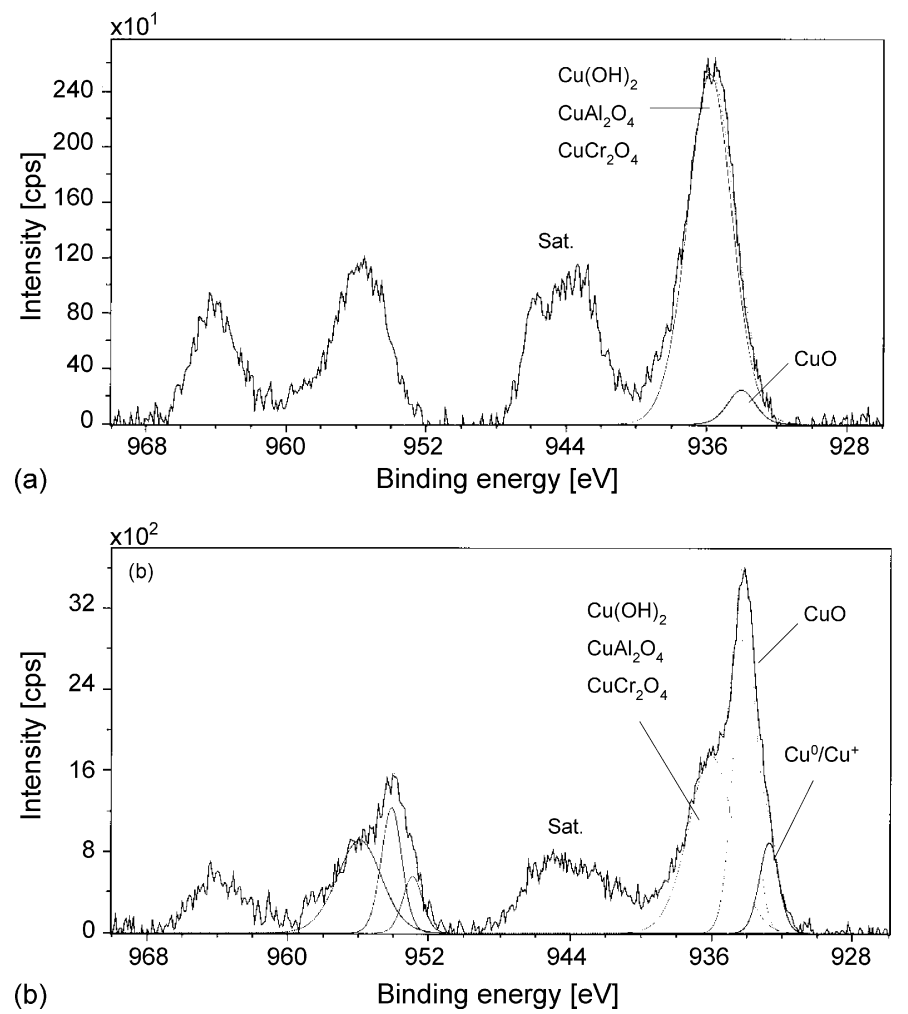

Fig. 6. $\mathrm{Cu} 2 \mathrm{p} \mathrm{X}$-ray photoelectron spectra of the Cr-doped catalyst (CZACr/i) after calcination (a) and after reduction (b).

a higher energy shoulder, which can be deconvoluted in two components: at $934.0 \mathrm{eV}$ assigned to $\mathrm{CuO}(17 \%)$, and above $935.0 \mathrm{eV}$ related to $\mathrm{Cu}^{2+}$ ions interacting with the hydroxyl groups of $\mathrm{ZnO}$ or in a $\mathrm{CuAl}_{2} \mathrm{O}_{4}$ spinel-type compound (13\%) $[27,30]$.

From Fig. 6(a), the calcined Cr-doped catalyst shows a unique large peak which consists of more than one contributions. The main part at $935 \mathrm{eV}$ is related to $\mathrm{Cu}^{2+}$ ions in the form of $\mathrm{Cu}(\mathrm{OH})_{2}$ or in the environment of a $\mathrm{CuAl}_{2} \mathrm{O}_{4}$ or $\mathrm{CuCr}_{2} \mathrm{O}_{4}$. A small contribution (6\%) is due to $\mathrm{CuO}$ at $934.0 \mathrm{eV}$. The satellite peak at $943 \mathrm{eV}$ is again observed, confirming the presence of $\mathrm{Cu}^{2+}$ ions. The reduced catalyst (Fig. 6(b)) does not show important modifications: contribution of $\mathrm{Cu}^{2+}$ in the form of $\mathrm{CuO}$ is bigger $(\sim 40 \%)$ and the surface presents a low content of copper as $\mathrm{Cu}^{+}$or $\mathrm{Cu}^{0}$.

The two catalysts - with and without chromium - have different behaviors towards reduction: the CZA catalyst is easily reduced to $\mathrm{Cu}^{+}$or $\mathrm{Cu}^{0}$ whereas the $\mathrm{CZACr}$ shows mainly the oxidized copper in form of the spinels. These observations agree with work reported by other groups [26-28,30-32].

\subsection{4. $T P R-T P O$}

The calcined and reduced catalysts were subjected to TPR and TPO measurements to provide information about the copper reducibility.

The TPR profiles of the calcined catalysts are shown in Fig. 7. The non-doped catalyst shows two broad peaks at 623 and $693 \mathrm{~K}$ whereas the doped catalyst presents a unique small peak at $593 \mathrm{~K}$. The presence of the doublet is explained either by the two steps reduction of copper [31,33] (Eq. (5)) or by the reduction of copper interacting with zinc

$\mathrm{Cu}^{2+} \rightarrow \mathrm{Cu}^{+} \rightarrow \mathrm{Cu}^{0}$

Moreover, it has been shown that a broad peak is characteristic of a strong interaction between two elements $\mathrm{Cu}$ and $\mathrm{Zn} \mathrm{[31]} \mathrm{and} \mathrm{that} \mathrm{copper} \mathrm{oxide} \mathrm{in} \mathrm{the} \mathrm{presence} \mathrm{of} \mathrm{zinc} \mathrm{is}$ reduced at lower temperatures than copper oxide alone [33-35]. As a result, the peak of the CZACr/i catalyst corresponds to the reduction of copper interacting with $\mathrm{Zn}$ or $\mathrm{Cr}$. The hydrogen

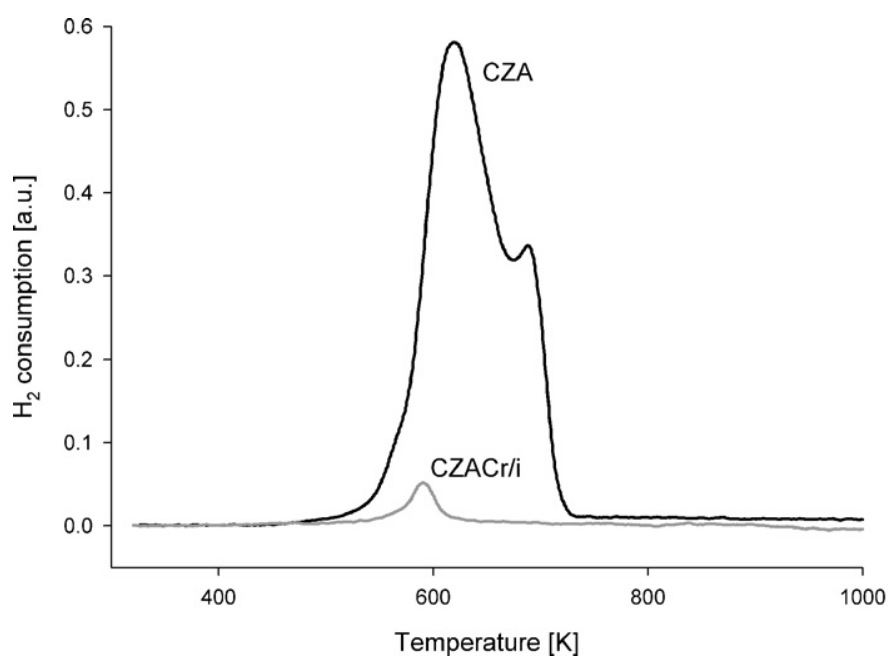

Fig. 7. TPR profiles of the calcined catalysts. 


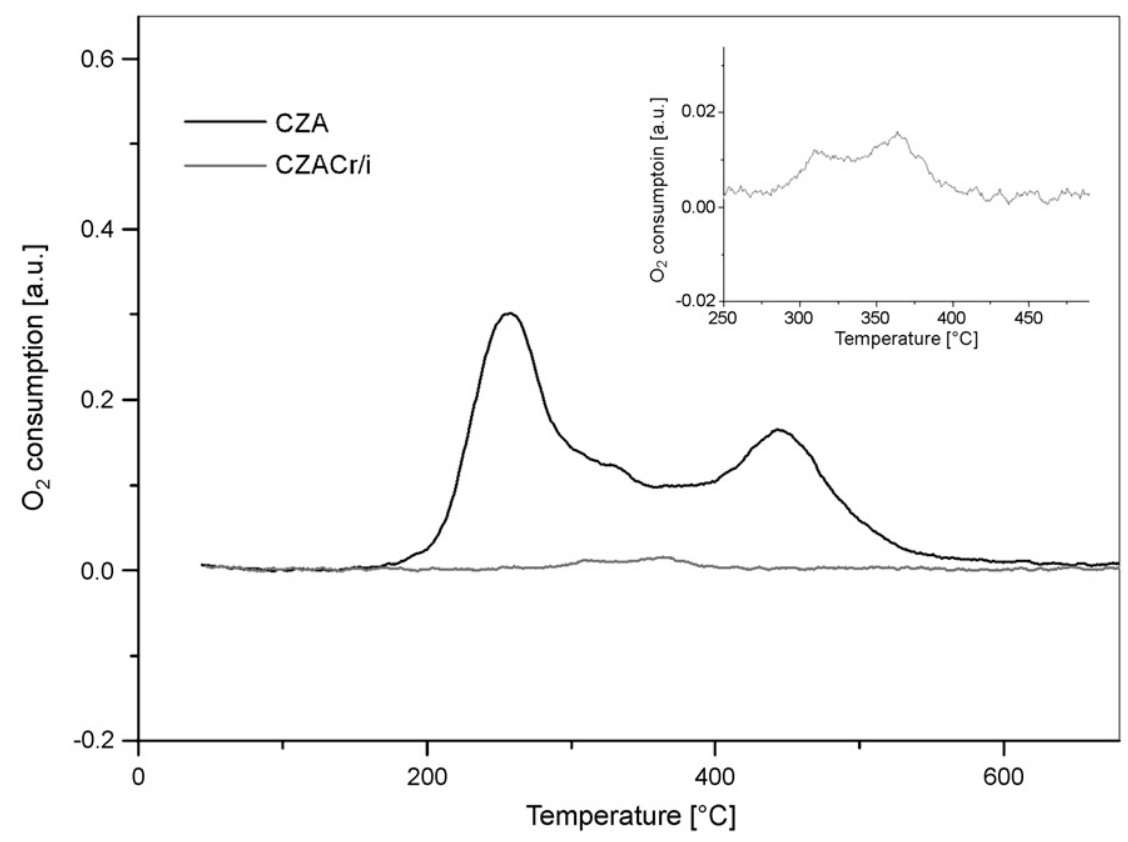

Fig. 8. TPO profiles of the reduced catalysts (inset: $\mathrm{CZACr} / \mathrm{i}$ ).

consumption of the doped catalyst is low because a spinel structure is difficult to reduce [36].

The TPO profiles of the reduced catalysts are shown in Fig. 8. The non-doped catalyst shows a multi-peak profile [30] and is attributed to the reverse reaction of Eq. (5). On the contrary, the doped catalyst is characterized by low oxygen consumption indicating that the Cr-doped catalyst is in the oxidized state.

\subsection{Catalytic activity}

A series of experiments was carried out by varying the contact time, i.e. changing the total flow rate while keeping methanol and oxygen concentration constant at 13 and $12 \%$, respectively. The effects of contact time and temperature on the methanol conversion and CO-selectivity (Eq. (6)) are found and presented in Fig. 9. The experimental error is estimated to be $\pm 5 \%$.

$S_{\mathrm{CO}}=\frac{C_{\mathrm{CO}}}{C_{\mathrm{CO}}+C_{\mathrm{CO}_{2}}}$

At longer contact times and higher temperatures the increased conversions were observed. Likewise, the CO-levels increase with increasing contact time and temperature.

Different reaction schemes have been suggested for the generation of CO by-product. Santacesaria and Carra [37] and Amphlett et al. [38] proposed a sequence of decompositionwater-gas shift (WGS) reaction: $\mathrm{CO}$ is a primary product subsequently converted into $\mathrm{CO}_{2}$ in the WGS reaction accompanied by $\mathrm{H}_{2}$ production. Parallel reactions between methanol SR and decomposition have been reported [39], with the $\mathrm{CO} / \mathrm{CO}_{2}$ ratio adjusted by the WGS equilibrium.

A direct mechanism was proposed initially by Takahashi et al. [40]: the methylformate reaction route where no WGS is involved. In this case methanol dehydrogenation (Eq. (7)) to methylformate takes place, followed by the hydrolysis to formic acid (Eq. (8)) which subsequently decomposes into $\mathrm{CO}_{2}$ and $\mathrm{H}_{2}$ (Eq. (9)). $\mathrm{CO}$ is proposed to be formed as a secondary product by the reverse WGS reaction (Eq. (10)).

$$
\begin{aligned}
& 2 \mathrm{CH}_{3} \mathrm{OH} \rightarrow \mathrm{HCOOCH}_{3}+2 \mathrm{H}_{2} \\
& \mathrm{HCOOCH}_{3}+\mathrm{H}_{2} \mathrm{O} \rightarrow \mathrm{HCOOH}+\mathrm{CH}_{3} \mathrm{OH} \\
& \mathrm{HCOOH} \rightarrow \mathrm{CO}_{2}+\mathrm{H}_{2} \\
& \mathrm{CO}_{2}+\mathrm{H}_{2} \rightarrow \mathrm{CO}+\mathrm{H}_{2} \mathrm{O}
\end{aligned}
$$

Fig. 10 shows the CO-selectivity plotted against methanol conversion and compared to the equilibrium selectivity calculated for the water-gas shift reaction (Eq. (4)). Thermodynamic

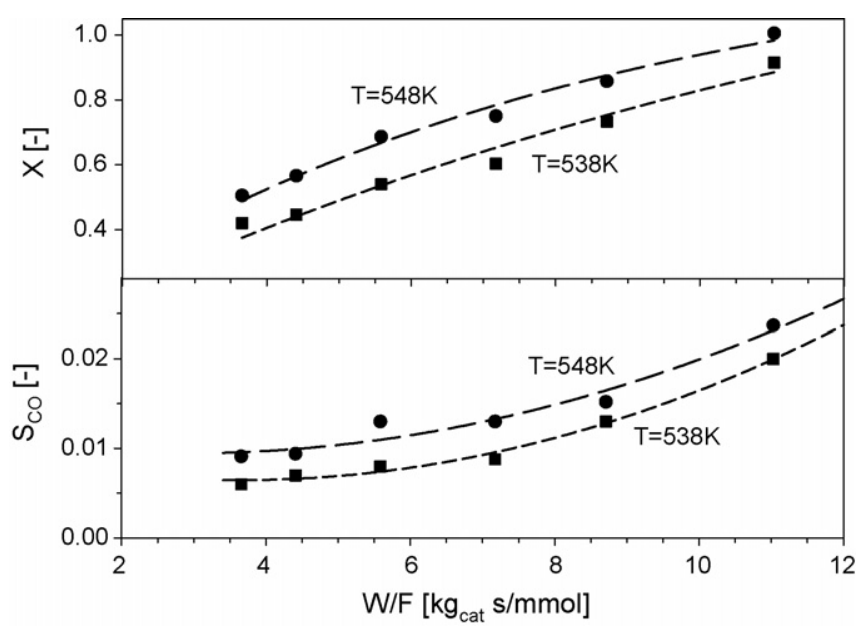

Fig. 9. Methanol conversion and CO-selectivity vs. contact time for oxidative steam-reforming over CZACr/i at 538 and $548 \mathrm{~K}$. Pressure $0.13 \mathrm{MPa}$, methanol: $13 \mathrm{~mol} \%$, oxygen: $12 \mathrm{~mol} \%$, water: $13 \%$, rest: argon. 


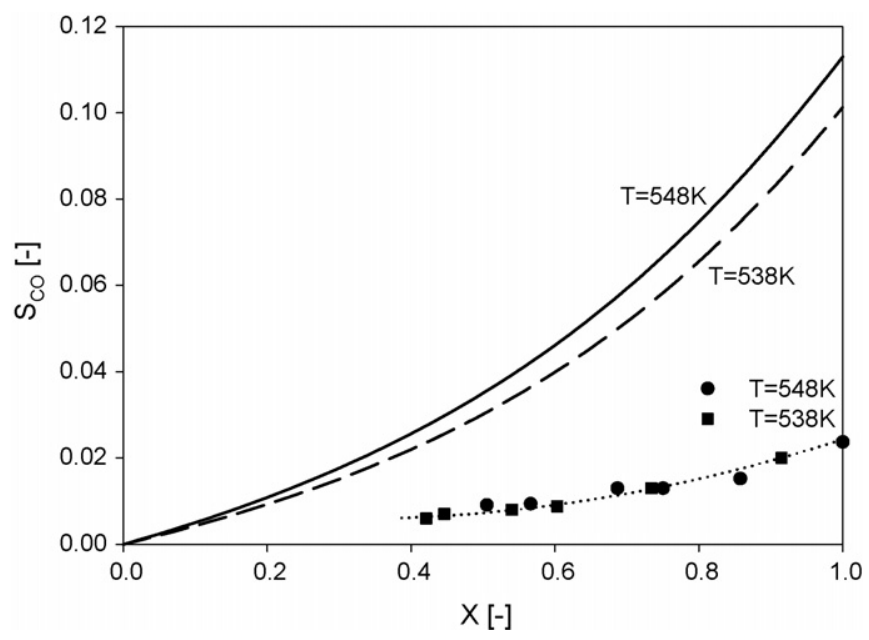

Fig. 10. $\mathrm{CO}_{2}$-selectivity as a function of methanol conversion $(\mathrm{CZACr} / \mathrm{i})$. Equilibrium (lines) and measured values (points) at $538 \mathrm{~K}$ and $548 \mathrm{~K}$.

data were taken from Reid et al. [41]. The product composition is seen to be far from equilibrium: CO-levels are well below those predicted by equilibrium for the WGS reaction. This result suggests that carbon monoxide is not formed as a primary product of methanol decomposition, but as a secondary product in a consecutive reaction. Similar results are reported in the literature confirming the above reaction mechanism [5,8,4244]. WGS can be neglected under the conditions of the SR reaction [45] although copper-zinc-alumina catalysts are known to be active for low temperature WGS reaction $[46,47]$. The lack of $\mathrm{CO}$ formation was explained by the surface blocking by the strongly adsorbed methanol and methylformate [45]. The concentration of carbon monoxide was about $2500 \mathrm{ppm}$ at complete conversion at $548 \mathrm{~K}$. This value is above the allowed limit, but it is adequate for the separation in a Pd membrane or by preferential oxidation $[1,6]$.

\subsection{Thermal behavior of the string reactor}

Oxidative steam-reforming was carried out over CZACr in the string reactor of $110 \mathrm{~mm}$ length. The reactor temperature was measured in the center of the reactor at different axial positions.

\subsubsection{Reactor dynamics during the start-up}

The transient thermal behavior during a start-up of the reactor for OSRM was studied by monitoring the temperatures at four axial positions: 8, 31, 62 and $105 \mathrm{~mm}$ and are shown in Fig. 11 as function of time. The initial temperature was $535 \mathrm{~K}$ and corresponded to the wall temperature of the reactor. At time $t=0$, the inert gas (Ar) was replaced by the reaction mixture (methanol 16.5\%, water $16.5 \%$ and oxygen $2 \%$ in Ar). The temperature at the reactor entrance $(8 \mathrm{~mm})$ increased rapidly within the first $10 \mathrm{~min}$ and reached steady state after $\sim 20 \mathrm{~min}$. The steep temperature rise is due to the fast exothermic methanol oxidation, which takes place in the first part of the reactor. With increasing distance from the reactor

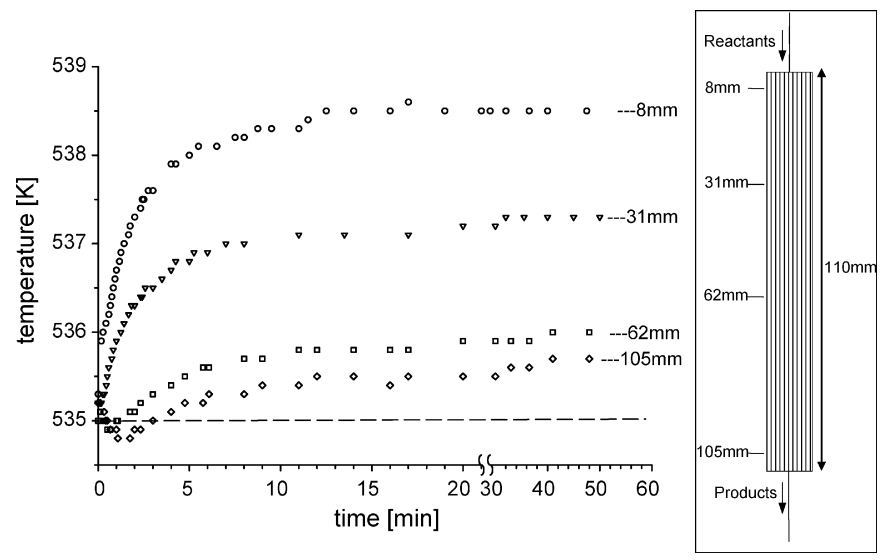

Fig. 11. Temperature variations as function of time during OSRM start-up at different axial positions. Catalyst: $\mathrm{CZACr} / \mathrm{i}$; W/F: $3.5 \mathrm{~kg}_{\text {cat }} \mathrm{s} / \mathrm{mmol}$; total flow rate $=100 \mathrm{~mL} / \mathrm{min}$.

inlet, the temperature rise is less pronounced, indicating the contribution of the endothermic steam-reforming. In the middle and end of the reactor (62 and $105 \mathrm{~mm}$ ), a temperature drop is observed over the first two minutes, followed by a rise up to the steady state. This temporary temperature decrease can be explained by a simultaneous endothermic reaction and a lack of energy supply from the methanol oxidation. But after $20 \mathrm{~min}$, a stationary axial temperature profile is established with a small hot-spot of $3.5 \mathrm{~K}$ at $8 \mathrm{~mm}$ from the reactor entrance.

\subsubsection{Thermal axial profile}

Stationary axial temperature profiles were measured in the reactor center for different reaction conditions (see Table 3 ). An example is given in Fig. 12 where the maximum temperature rise of $3.3 \mathrm{~K}$ is near the reactor entrance. At longer distances the temperature decreases and reaches asymptotically the wall temperature. Due to the high thermal conductivity of the catalytic brass-wires $(\lambda=118 \mathrm{~W} /(\mathrm{m} \mathrm{K})$ the energy produced by fast methanol oxidation is efficiently transferred to the reactor center and exit, where the endothermic steam-reforming takes place. Compared to the nearly isothermal behavior of the string reactor, a pronounced temperature gradient was observed in a conventional fixed bed reactor. The latter was packed by a commercial $\mathrm{Cu} / \mathrm{Al}_{2} \mathrm{O}_{3}$ with a particle diameter of $0.48 \mathrm{~mm}$,

Table 3

Characteristics of OSRM in the string reactor and in the fixed-bed reactor (methanol 16.5 vol.\%, water 16.5 vol.\%, oxygen 2 vol.\%, in Ar; total flow rate $100 \mathrm{~mL}(\mathrm{STP}) / \mathrm{min})$

\begin{tabular}{lll}
\hline & String reactor & Fixed-bed reactor \\
\hline Catalyst & $\mathrm{CZACr} / \mathrm{i}$ & $\mathrm{Cu} / \mathrm{Al}_{2} \mathrm{O}_{3}$ \\
$T_{0}(\mathrm{~K})$ & 535 & 481 \\
$\mathrm{~W} / \mathrm{F}\left(\mathrm{kg}_{\text {cat }} \mathrm{s} / \mathrm{mmol}\right)$ & 3.5 & 0.06 \\
Void fraction & 0.33 & 0.50 \\
$X\left(\mathrm{CH}{ }_{3} \mathrm{OH}\right)$ & 0.43 & 0.43 \\
$S(\mathrm{CO})$ & 0.009 & 0.036 \\
\hline
\end{tabular}




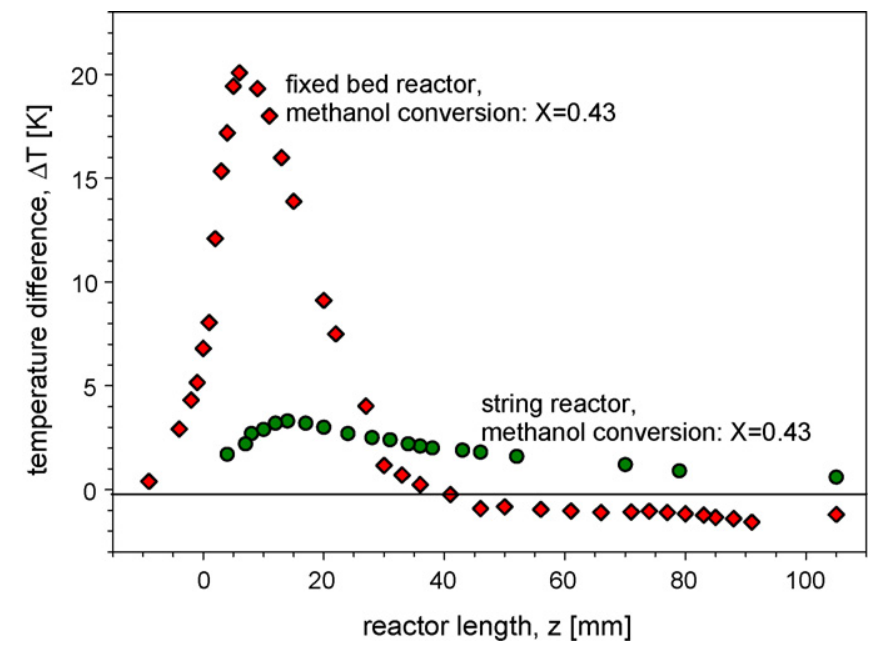

Fig. 12. Temperature axial profile during OSRM reaction at a methanol conversion of $43 \%$. Catalyst: $\mathrm{CZACr} / \mathrm{i} ; \mathrm{W} / \mathrm{F}=3.5 \mathrm{~kg}_{\text {cat }} \mathrm{s} / \mathrm{mmol}$; total flow rate $=100 \mathrm{~mL} / \mathrm{min}$.

which corresponds to the diameter of the brass wires used for the string reactor. The catalyst particles were diluted with quartz beads in order to compare the temperature profile with the one in the string reactor at the same conversion and on the same reactor length. The characteristics of the fixed bed compared to the string reactor are summarized in Table 3. The measured profiles are shown in Fig. 12. At the entrance of the reactor, the temperature increases drastically giving a hot-spot of $20 \mathrm{~K}$ at a $7 \mathrm{~mm}$ distance, whereas in the second part of the reactor the temperature is $2 \mathrm{~K}$ below the wall temperature (cold-spot).

4.4.2.1. Influence of methanol conversion. The effect of methanol conversion on thermal axial profile was studied by varying the reactor wall temperature. Fig. 13 illustrates the measured profiles for three different reactor temperatures: 525,

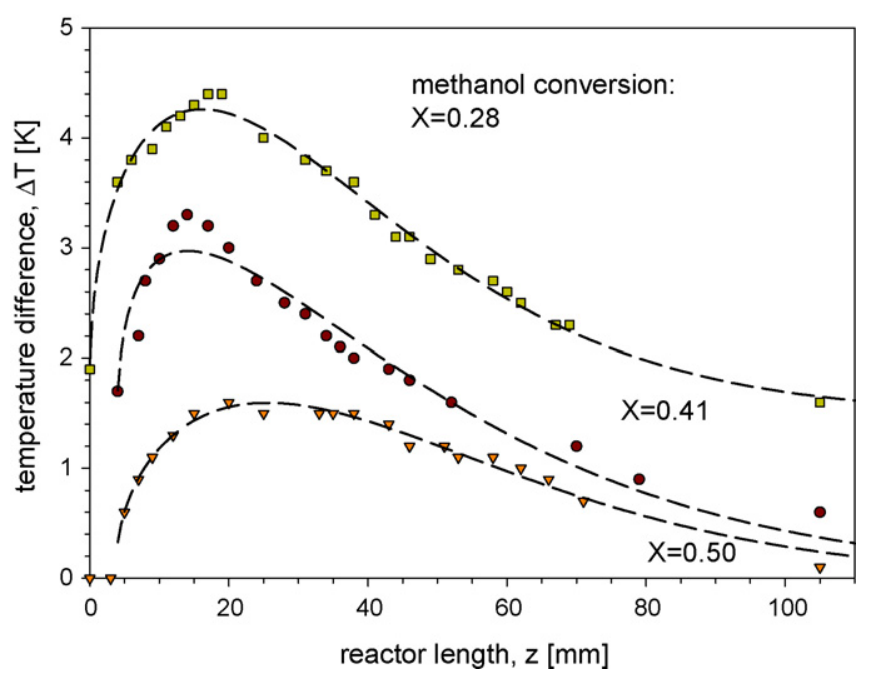

Fig. 13. Temperature axial profiles during OSRM reaction at three different methanol conversions. Catalyst: $\mathrm{CZACr} / \mathrm{i} ; \mathrm{W} / \mathrm{F}=3.5 \mathrm{~kg}_{\text {cat }} \mathrm{s} / \mathrm{mmol}$; total flow rate $=100 \mathrm{~mL} / \mathrm{min}$.
535 and $550 \mathrm{~K}$ corresponding to methanol conversions of 28, 43 and $50 \%$, respectively. With increasing methanol conversion, the temperature profile becomes more flat due to the increased energy consumption by steam-reforming. As methanol oxidation is fast compared to reforming, the two reactions can be considered as being consecutive. With the methanol/oxygen ratio of $a=0.12$, complete oxygen consumption corresponds to $8 \%$ of methanol conversion. Higher methanol conversions indicate a contribution of the steam-reforming. Methanol conversion can also be influenced by changing the contact time at constant temperature. The observed temperature profiles show the same tendency: they become flatter with increasing conversion and the hot-spot disappeared for conversions $>75 \%$ [48].

\section{Conclusions}

Thermal coupling of methanol steam-reforming and its oxidation was performed by carrying out the oxidative steamreforming of methanol in a compact string reactor with catalytic brass wires. This allows hydrogen production in authermal mode. The string reactor presents micro-channels for the reacting gases between the wires placed in parallel into a tube and showing hydrodynamics similar to multi-channel micro-reactors. The catalytic wires were prepared by Al-alloy formation on the surface of brass wires followed by partial leaching of $\mathrm{Al}$ in basic solution. The catalyst presents a porous layer with the morphology of Raney metals and the chemical composition consistent with the $\mathrm{Cu} / \mathrm{Zn} / \mathrm{Al}$-mixed oxide. The catalyst surface was additionally modified by incorporating chromium leading to $\mathrm{Cr} / \mathrm{Cu}$-spinel. This decreases the degree of the reduction of copper oxide and its sintering leading to a stable catalyst. The selectivity towards carbon dioxide was $98 \%$ for a methanol conversion of $91.5 \%$ being higher than predicted for the water-gas shift equilibrium. It was concluded that carbon monoxide is produced from the reverse water-gas shift reaction when methanol has undergone almost complete conversion. Thermal axial profiles showed a difference of $3.5 \mathrm{~K}$ along the string reactor. In comparison, in the fixed-bed reactor the temperature change was $\sim 25 \mathrm{~K}$. Therefore, the microstructured string reactor with brass wires improves heat transfer allowing a close to isothermal performance of OSRM. String reactor presents a short start-up and a fast transient behavior showing a rapid temperature change when adjusting the oxygen amount introduced into the reactor. A further advantage is that the micro-structured string reactor with outer diameters in the centimeter range can be easily integrated in traditional processes.

\section{Acknowledgements}

The financial support from the Swiss National Science Foundation and the Max-Buchner-Forschungsstiftung is gratefully acknowledged. The authors thank Brian Senior and Nicolas Xanthopoulos for collaboration in the catalyst characterization by XPS and SEM. 


\section{References}

[1] L.F. Brown, Int. J. Hydrogen Energy 26 (2001) 381.

[2] K. Ledjeff-Hey, V. Formanski, T. Kalk, J. Roes, J. Power Sources 71 (1998) 199.

[3] J.R. Rostrup-Nielsen, Phys. Chem. Chem. Phys. 3 (2001) 283.

[4] B. Höhlein, M. Boe, J. Bogild-Hansen, P. Bröckererhoff, G. Colsman, B. Emonts, R. Menzer, E. Riedel, J. Power Sources 61 (1996) 143.

[5] P. Reuse, A. Renken, K. Haas-Santo, O. Görke, K. Schubert, Chem. Eng. J. 101 (2004) 133.

[6] N. Edwards, S.R. Ellis, J.C. Frost, S.E. Golunski, A.N.J.V. Keulen, N.G. Lindewald, J.G. Reinkingh, J. Power Sources 71 (1998) 123.

[7] K. Geissler, E. Newson, F. Vogel, T.B. Truong, P. Hottinger, A. Wokaun, Phys. Chem. Chem. Phys. 3 (2001) 289.

[8] J. Agrell, H. Birgersson, M. Boutonnet, J. Power Sources 106 (2002) 249.

[9] S. Velu, K. Suzuki, M.P. Kapoor, F. Ohashi, T. Osaki, Appl. Catal. A: Gen. 213 (2001) 47.

[10] K. Geissler, Swiss Federal Institute of Technology, EPF-Lausanne, No. 2442, 2002.

[11] M. Schuessler, O. Lamla, T. Stefanovski, C. Klein, D. Megede, Chem. Eng. Technol. 24 (2001) 1141.

[12] B. Lindström, J. Agrell, L.J. Pettersson, Chem. Eng. J. 93 (2003) 91.

[13] L. Kiwi-Minsker, O. Wolfrath, A. Renken, Chem. Eng. Sci. 57 (2002) 4947.

[14] O. Wolfrath, Thèse No. 2384, EPFL, 2001.

[15] C. Horny, L. Kiwi-Minsker, A. Renken, Chem. Eng. J. 101 (2004) 3.

[16] L. Kiwi-Minsker, CHIMIA 56 (2002) 159.

[17] J. Agrell, M. Boutonnet, J.L.G. Fierro, Appl. Catal. A: Gen. 253 (2003) 213.

[18] Y. Choi, H.G. Stenger, Appl. Catal. B: Environ. 38 (2002) 259.

[19] S. Murcia-Mascaros, R.M. Navarro, L. Gomez-Saneiro, U. Constantino, M. Nocchetti, J.L.G. Fierro, J. Catal. 198 (2001) 338.

[20] H.E. Curry-Hyde, M.S. Wainwright, D.J. Young, Appl. Catal. 77 (1991) 75.

[21] J.R. Mellor, N.J. Coville, A.C. Sofianos, R.G. Copperthwaite, Appl. Catal. A: Gen. 164 (1997) 185.

[22] J. Toyir, M. Saito, I. Yamauchi, S. Luo, J. Wu, I. Takahara, M. Takeuchi, Catal. Today 45 (1998) 245.

[23] M.V. Twigg, M.S. Spencer, Appl. Catal. A: Gen. 212 (2001) 161.

[24] Z. Wang, J. Xi, W. Wang, G. Lu, J. Mol. Catal. A: Chem. 191 (2003) 123.

[25] B. Lindström, L.J. Pettersson, Catal. Lett. 74 (2001) 27.
[26] L. Yong-Feng, D. Kin-Fa, L. Wei-Ming, Int. J. Hydrogen Energy 29 (2004) 1617.

[27] I. Melian-Cabrera, M.L. Granados, P. Terreros, J.L.G. Fierro, Catal. Today 45 (1998) 251.

[28] G.R. Sheffer, T.S. King, J. Catal. 115 (1989) 376.

[29] J. Batista, A. Pintar, D. Mandrino, M. Jenko, V. Martin, Appl. Catal. A: Gen. 206 (2001) 113.

[30] L. Alejo, R. Lago, M.A. Pena, J.L.G. Fierro, Appl. Catal. A: Gen. 162 (1997) 281.

[31] J. Agrell, M. Boutonnet, I. Melian-Cabrera, J.L.G. Fierro, Appl. Catal. A: Gen. 253 (2003) 201.

[32] S. Velu, K. Suzuki, C.S. Gopinath, H. Yoshida, T. Hattori, Phys. Chem. Chem. Phys. 4 (2002) 1990.

[33] B. Lindström, L.J. Pettersson, P. Govind Menon, Appl. Catal. A: Gen. 234 (2002) 111.

[34] J.L.G. Fierro, M. Lo Jacono, M. Inversi, P. Porta, F. Cioci, R. Lavecchia, Appl. Catal. A: Gen. 137 (1996) 327.

[35] J.P. Shen, S. Chunshan, Catal. Today 77 (2002) 89.

[36] H. Agaras, G. Cerrella, M.A. Laborde, Appl. Catal. 45 (1988) 53.

[37] E. Santacesaria, S. Carra, Appl. Catal. 5 (1983) 345.

[38] J.C. Amphlett, M.J. Evans, R.F. Mann, R.D. Weir, Can. J. Chem. Eng. 63 (1985) 605.

[39] J.C. Amphlett, R.F. Mann, B.A. Peppley, Stud. Surf. Sci. Catal. 81 (1994) 409.

[40] H. Takahashi, N. Takezawa, H. Kobayashi, Appl. Catal. 2 (1982) 363.

[41] R.C. Reid, J.M. Prausnitz, B.E. Poling, McGraw-Hill International Editions, 1986.

[42] H. Purnama, T. Ressler, R.E. Jentoft, H. Soerijanto, R. Schlögl, R. Schomäcker, Appl. Catal. A: Gen. 259 (2004) 83.

[43] J.P. Breen, F.C. Meunier, J.R.H. Ross, Chem. Commun. (1999) 2247.

[44] J.P. Breen, J.R.H. Ross, Catal. Today 51 (1999) 521.

[45] C.J. Jiang, D.L. Trimm, M.S. Wainwright, Appl. Catal. A: Gen. 93 (1993) 245.

[46] M.J.L. Ginés, A.J. Marchi, C.R. Apesteguia, Appl. Catal. A: Gen. 154 (1997) 155.

[47] J.R. Mellor, N.J. Coville, A.C. Sofianos, R.G. Copperthwaite, Appl. Catal. A: Gen. 164 (1997) 171.

[48] C. Horny, Développement d'un réacteur microstructuré basé sur des filaments métalliques catalytiques, Production autotherme d'hydrogène par steam-reforming oxydatif du methanol, No. 3271, Ecole polytechnique fédérale de Lausanne, 2005. 